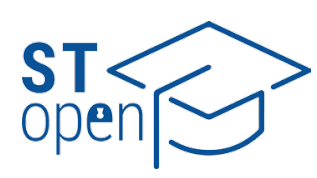

(c) 2021 The Author(s)

ST-OPEN @ 202

\title{
A theological approach to mitigating the impacts of the SARS CoV-2 pandemic
}

\section{Ivica Jurić (i)}

Catholic Faculty of Theology in Split, Split, Croatia
Correspondence to:

Ivica Jurić

Catholic Faculty of Theology in Split, Zrinsko-

Frankopanska 19, 21000 Split, Croatia

ivicajurich@gmail.com

Cite as:

Jurić I. A theological approach to mitigating the impacts of the SARS CoV- 2 pandemic. ST-OPEN. 2021; 2: e2021.2119.53.

DOl:

https://doi.org/10.48188/so.2.11
Objective: Investigate the hardships caused by the SARS CoV-2 pandemic in the social domain, and especially church life in Croatia. Additionally, the study aimed to study the guidelines for the faithful and society at large established by the Catholic Church. Further, guidelines are proposed to improve specific pastoral practices in the context of the pandemic.

Methods: This paper uses the scientific research method of pastoral judgment developed by the Lateran School (Lanza, 2008; Čondić, 2013; Vranješ, 2013).

Results: Following a theological and pastoral analysis of the impacts of the SARS CoV-2 pandemic, particularly in the ecclesiastical domain, as well as a study of the guidelines issued by both the universal and local Church and prominent theologians, guidelines for improving the existing practice were proposed in six areas: Discovering the meaning of suffering (life); To reject suffering is to reject love; Where am I in the era of the SARS CoV-2 pandemic?; Liberating men from fear; Paying attention to the collocutor; and The parish community is a space for everyone.

Conclusion: Despite being taken by surprise by the initial outbreak of the SARS CoV-2 pandemic, the Catholic church in Croatia has considerable potential and has engaged in a wide scope of activities to mitigate the impact of the pandemic. This primarily has to do with bolstering the spiritual dimension in the faithful. Faith overcomes fear, gives meaning to suffering, and acts as a life force that may help heal the whole of society through fellowship and tangible support to those at-risk during the pandemic.

\section{Introduction}

This paper considers the impacts of the SARS CoV-2 pandemic on day-to-day life, as well as what can be done by the Church to mitigate its consequences. It strives to elucidate certain phenomena that - although not completely novel - have surfaced during the pandemic, and the subsequent slowing down and interruption of the familiar rhythm of life. In this 
sense, we may speak of the heuristic dimension of the pandemic that has opened our eyes and shined an even brighter spotlight on the state of our society. Of course, it has also opened up a barrage of questions looking for answers. First and foremost, they have to do with recognizing kairos (an opportune moment to act) in the religious context and, consequently, articulating an authentic response around a deeper devotion to living the gospel in the present. The pandemic may not be God's word to humanity, but it certainly is an opportunity to rethink our way of life. This is confirmed by a recent study from Italy, which found that only very few respondents thought of the pandemic as God's punishment (Pace, 2021, p. 32). Another Italian study found that the devout moved even closer to God, prayer, and Church activities during the SARS CoV-2 pandemic (Maccioni, 2021).

Both the Bible and life experience have taught us that adversity provides an opportunity to self-reflect, contemplate the self, and change our lives. Using the theological and pastoral methodology of the Lateran School (Lanza, 2008; 2010; Čondić, 2013; Vranješ, 2013), we therefore seek to identify - beyond the obvious negatives - new possibilities or duties that may contribute to a greater humanization of society. Viewed in the broader context of contributing to the consecration and salvation of the world, this is, in a nutshell, our mission as a community (Drugi vatikanski koncil, 1986, pp. 40-44). This is not a timeless, immutable mission - rather, it needs to be carefully reconsidered in light of living circumstances, as well as constantly validated (Mette, 1997, p. 41). Therefore, we first need to explore the living circumstances, and then, based on our insights and the Church's guidelines, design activities geared toward carrying out a more authentic mission during the SARS-CoV-2 pandemic.

\section{Life during the coronavirus pandemic}

It has now been more than a year and a half since the 2019 coronavirus disease (COVID-19) outbreak in China, but victory over the virus remains out of reach (Matulić, 2020, p. 746). The impact of the pandemic can be seen daily in all areas of life. The tiny, invisible virus features in every conversation, fear, and plan. As our health statuses differ, the so-called vulnerable populations are particularly at risk (the elderly, sick and infirm, people suffering from chronic respiratory diseases, heart and liver diseases, high blood pressure, cancer, diabetes, etc.) (Gallo Martin et al., 2021, pp. 1-10). Even among these populations, it is those in failing health, who live alone or are isolated in nursing homes, as well as inpatients with COVID-19 who have been deprived of the physical closeness of their loved ones, who have been hit the hardest.

The pandemic has dealt a hard blow to both individuals and families. Economic uncertainty and the collapse of countless small businesses - in Croatia, the transportation, tourism, and hospitality sectors have suffered the hardest blows - have engendered other family-related issues, driving up the rates of divorce and domestic violence (Državni zavod za statistiku, 2021). Society at large has been struck by unprecedented and - until recently - unimaginable measures: borders and schools have closed, sporting and cultural events have been cancelled, public transportation has been cut back, restaurants and hotels shut down, and social life has all but stopped. It is almost impossible to list every change or 
restriction that has been, to a greater or lesser extent, implemented by states and local communities, depending on the epidemiological situation in the respective state or region. If we compare Croatia with neighboring countries, regarding the consequences of the pandemic, Croatia has not fared any worse than its neighbors. Most certainly, recent experience from the war for independence helped Croatians react adequately to the pandemic (Tokalić et al., 2021).

The coronavirus pandemic has brought into an unusually sharp focus the fact that all reality - global and human - is in many aspects interconnected, interactive. This means that the only way out of this situation is rediscovering reciprocity, the sense of belonging to a community that requires our care (Cecchin, 2021, p. 25). The Church has addressed this through the writings of the Pontifical Academy for Life (Pontifical Academy for Life, 2020a), as well as countless interventions (speeches, homilies, catecheses) by the Pope, most notably in the social encyclical Fratelli tutti (Franjo, 2020e, pp. 32-36), a series of catecheses titled "Healing the World" (Franjo, 2020a; 2020b; 2020c), as well as a particularly dramatic address delivered to an empty St. Peter's Square in Rome on 27 March 2020 (Franjo, 2020d). While addressing the frightful consequences of the pandemic, the Pope also brought up spiritual problems that plague the world: greed for profit, materialism, false sense of security, egotistic sense of omnipotence, disobedience to God's calls, ignorance of great injustices, and various forms of violence. The following words resonated particularly strongly: "In this world, that you love more than we do, we have gone ahead at breakneck speed, feeling powerful and able to do anything. Greedy for profit, we let ourselves get caught up in things, and lured away by haste. We did not stop at your reproach to us, we were not shaken awake by wars or injustice across the world, nor did we listen to the cry of the poor or of our ailing planet. We carried on regardless, thinking we would stay healthy in a world that was sick. Now that we are in a stormy sea, we implore you: "Wake up, Lord!” (Franjo, 2020d). Pope Francis spoke about our ailing planet and world. Of course, the Pope was referring to the illness of the spirit and called for drawing a clear line between that which is transient and needless and that which is intransient and redemptive. In short, a return to Christ and his values is the way out that will bring peace and security to the society leaden with uncounted problems.

Countless times since the beginning of the pandemic, the Pope has called on both the faithful and the whole world to join forces in the fight against the virus and show solidarity with the weakest. We will underscore only his recent appeal: Everyone, especially the most vulnerable among us, requires assistance. Only together can we build a fairer and healthier world. All of us are called to combat the pandemic. Pope Francis (2021) declared, "Vaccines are an essential tool in this fight”. Incidentally, Pope Francis and Pope Emeritus Benedict XVI received the vaccine in January 2021 (Vatican News, 2021). Additionally, in December 2020, the Congregation for the Doctrine of the Faith issued a statement that "all vaccinations recognized as clinically safe and effective can be used in good conscience" but that "vaccination is not, as a rule, a moral obligation and that, therefore, it must be voluntary" (Congregation for the Doctrine of the Faith, 2020). 


\section{Consequences of the COVID-19 pandemic on the life of the Church}

The pandemic has imposed constraints on the church's liturgical and pastoral activities. The first lockdown was the most precarious, as celebrating public Mass, holding parish catechesis, and celebrating the sacraments of First Communion and Confirmation had to be put on hold (Hrvatska biskupska konferencija, 2021). The regular family blessing, access to the Sacrament of Penance, and all other religious gatherings were also limited. Due to the ban or restriction of the number of attendants, the number of Church weddings decreased radically, so 2020 saw more civil (57.15\%) than church weddings (42.84\%) for the first time in recent Croatian history (Jurasić, 2021). In total, $69.2 \%$ fewer marriages were conducted between March and May 2020 compared to the five-year average for that period before the pandemic (Državni zavod za statistiku, 2021).

Another consequence that has been observed in Croatia is the general absence of children from Sunday Masses. More specifically, after the two-month ban on public Mass during the spring lockdown, adults and children seem to have gotten used to not participating in Sunday Holy Mass. Many parishes and religious institutions have encountered new pastoral challenges and material hardships. There have been, however, some positive indicators. During the ban, many believers have discovered the importance of spirituality and common prayer within the family. More specifically, this was an opportunity to develop a personal relationship with God through reading and meditation on God's word that was in a way 'liberated' from regular schedules and liturgical patterns. Many priests and lay people sought to convey the message of the gospel to those in need of encouragement and comfort through social and other media. For instance, one priest who served in a hospital as hospital chaplain (and became infected himself) comforted the ailing with daily messages and prayers during their fight against the virus, and then published a well-received book about his experience (Doljanin, 2021). The pandemic has also shown that in certain situations, even those who are indifferent to or at odds with religion suddenly developed sensitivity to spiritual topics (Langer \& Halík, 2021). One Croatian study found that the crisis deepened people's thirst for God. More specifically, out of 739 respondents, 570 (77.13\%) admitted that the pandemic inspired them to reconsider their life values, while 169 (22.87\%) answered contrarily (Begić \& Brgles, 2021).

Still, whether the hardships of the coronavirus pandemic will have raised our awareness and made us kinder or whether - once things settle - we will go back to business as usual, remains to be seen. Might the forceful restrictions make people more attentive to life, more compassionate toward others, and more sensitive to the environment? Might they become aware that they have long been tired of relentless change, all manners of compulsions, and the tyranny of happiness, success, and popularity? Perhaps they might slow down the cut-throat pace and realize that change is not the only guarantee of the future of society - that what has proven tried and true over the centuries may also be worth preserving. Much more than the feverish change, the world today needs conservation efforts (Anders, 2004, p. 76).

In a series of catecheses entitled "Healing the World" (Franjo, 2020a; 2020b; 2020c) the Pope spoke about the need for global solidarity, the importance of subsidiarity and synodality, and the care for the common good - our common home, the Earth. To this end, he re- 
minded that the coronavirus pandemic had unearthed many of our weak spots - physical, social, and spiritual. In particular, he underscored the great inequality of access to health care (vaccines), technology, and education. Due to the profusion of injustices in the world, many have lost hope, and uncertainty and anxiety are ever on the rise. Consequently, the Pope proposed that to get out of this pandemic, we need to find not only the cure for the coronavirus - which is of utmost importance - but also a remedy for the "great socio-economic viruses” (Franjo, 2020c). The pandemic has been a litmus test of inequality, the privilege of the rich, and the disregard of the poor. This inequality has become palpable recently in vaccine ordering and, consequently, the shameful disparity in vaccination rates in wealthy and poor countries (Mathieu et al., 2021). Unfortunately, we are witnessing what Pope Francis and many others have been cautioning against tirelessly: the rule of money and profit at the expense of human lives, many of whom could have been saved if only those in power had been less greedy.

\section{Distrust in institutions, science, and the media}

Like a microscope, the coronavirus pandemic has brought into focus what has been around for years, but has, in many cases, remained in the background. It is the issue of loneliness, the lack of meaning in life, inequality, and abuse of power. One of the phenomena that has accompanied the pandemic is certainly the unprecedented degree of public lack of trust in science and institutions. Various freedoms have been violated, and the chasms between the poor and the rich are only growing wider. Particularly painful is the floundering of scientists since the beginning of the pandemic, their disagreement and inconsistency (Risch, 2020, pp. 1218-1226). Distrust in the media is also on the rise. If some portion of society used to unquestioningly trust the media, this trust seems to have been severely shaken (Misselhorn, 2018, p. 167; Tsao et al., 2021; Bradshaw, Bailey, \& Howard, 2021; Selak, 2019, pp. 105-111).

The pandemic has posed various questions and ethical doubts. Everyone is free to think whatever they wish about the (non)hazard of the coronavirus pandemic, but this freedom does not release them from responsibility to others. In other words, personal opinions and actions should not and cannot - directly or indirectly - jeopardize the health of others. The protection of life and health must not be left to the will of the individual - especially not in a pandemic, a global threat to life and health. A case like this requires special attention and concern of the general public, particularly when it comes to caring for vulnerable populations. Putting state institutions aside, in these circumstances, caring for the weak is the duty of every Christian. Accordingly, the Catechism of the Catholic Church reminds people that: "Life and physical health are precious gifts entrusted to us by God. We must take reasonable care of them, taking into account the needs of others and the common good. Concern for the health of its citizens requires that society help in the attainment of living-conditions that allow them to grow and reach maturity: food and clothing, housing, health care, basic education, employment, and social assistance” (Katekizam Katoličke Crkve, 2016, p. 2288). We discuss what the Church can and should do to bring people closer to God and God closer to people and mitigate the consequences of the pandemic in more detail in the third section of this paper. 
When it comes to the perspective of faith and natural sciences on the coronavirus phenomenon, the Church generally places great trust and respect into scientific insights. The Catholic Church believes in a single truth at the foundation of all reality, and this may be reached in two different but nonexclusive and complementary ways: the path of faith and the path of reason (science). From the very beginning, it has strived to keep at equal distance from fideism and scientism, looking at faith and reason as the two wings with which one rises to perceive reality (Ivan Pavao II, 1999). Science elucidates the world, and faith reveals the meaning of life, the meaning of all creation. Science describes what is, and faith opens the eyes to what can and should be. Science sees objects, things, phenomena, but faith demands that our fellow man be seen as an agent, a person with equal dignity (Vučković, 2016, p. 44). The Church recognizes and respects the autonomy of science (Drugi vatikanski koncil, 1986, p. 36) and the political community whose role is to care for the common good (Drugi vatikanski koncil, 1986, p. 74). However, in the search for the meaning of human suffering and the answer to that uneasy why, the Church directs its view toward Jesus Christ and seeks answers to its suffering in His suffering and resurrection (Hrvatska biskupska konferencija, 2021; Matulić, 2020, pp. 753-754).

\section{Individualism and forgetting God}

People have always feared death. In our time, when the divinization of the body has reached its peak, the fear of death has become even more unchecked. On the one hand, death is so ubiquitous a phenomenon that it is almost banal; on the other, it has been all but banished from public discourse and driven to the edge of consciousness. The coronavirus pandemic has certainly added insult to the fear of death, the mother of all fears (Ratzinger, 2014, p. 96). We have become a threat to our peers - possible carriers of a deadly virus. This is painfully obvious in how we treat the elderly and the solitary, who have become even lonelier during this pandemic. Individualism has already reigned supreme as the defining phenomenon of the postmodern Western man; today, as a consequence of the pandemic, it is even more conspicuous. In his post-synodal exhortation entitled "Amoris laetitia - The Joy of Love," where he summarized the conclusions of two synods on the family, Pope Francis cited individualism as one of the obstacles to the success of the Church's mission in the field of family pastoral care. The Pope cautioned that extreme individualism "weakens family bonds and ends up considering each member of the family as an isolated unit, leading in some cases to the idea that one's personality is shaped by his or her desires, which are considered absolute" (Franjo, 2016, p. 33). Indeed, the culture of individualism, which may without exaggeration be called culture of hedonism, strives for possession and pleasure at all costs. It elevates self-gratification above responsibility for others and the common good. It hardly wants to hear about the sacrifice for others. Consequently, it gives birth to a lifestyle that is opposed to life and suppresses entering into marriage, ridding society of its foundation.

A society without affiliations and strong ties can easily turn into a crowd of loners, where everyone is a stranger and deserves only mistrust - as does the future, which is increasingly gloomy. Individualism, as one of the key features of the culture of the postmodern nomad, has thus led us to ubiquitous dissatisfaction instead of the promised self-realization (Franjo, 2014, pp. 67-97). The coronavirus pandemic, and especially the lockdown, 
only deepened the isolation of lonely, atomized masses. COVID-19 patients have died and are dying in hospitals without the physical closeness of their loved ones. Unfortunately, at the beginning of the pandemic, they would also die without a priest, without any solace or relief of faith during difficult times that might have been provided by the sacraments of Holy Confession, Anointing of the Sick, and Communion.

After the initial confusion, priests were able to rally and be with the infected, as far as epidemiological measures allowed. Many priests, as well as nuns, became infected by serving others and even died from the infection. Data show that 270 priests died in Italy (Ognibene, 2021; Benotti, 2021), while India lost 210 priests and 205 nuns, etc. (Gomes, 2021). This clearly demonstrates that the spiking of fear and anxiety, which have taken their toll on the spiritual and physical health of society, has been justified. The coronavirus pandemic has been driving a parallel pandemic of fear and anxiety. The escalation in psychological issues (even in children), especially anxiety and depression, has become apparent to many. Some even talk of a new kind of post-traumatic stress disorder (Bogdan, 2020; Jakšić, 2021, pp. 74-75).

The growing fear and anxiety may be considered from a theological standpoint. More specifically, even long before the coronavirus pandemic, Western men had forgotten God and chosen to build their own (earthly) kingdom over the kingdom of God. Unfortunately, Etsi Deus non daretur (as if there were no God) is no longer just a methodological principle of scientific research; it has become a life principle of ever-growing masses, which has reduced the horizon of reflecting on life only to the earthly, empirical reality. The observable world has thus become the only authority; man has ceased to look beyond it for anything worthy of observation. This, in Tillich's words, subjective forgetting of what objectively and unconditionally concerns us is becoming more apparent day in and day out. Eschatology, the study of the ultimate destiny, is increasingly secularized for the postmodern man, understood as the development of own resources, and deprived of openness to the transcendent (Kovač, 2020, pp. 757-775; Taylor, 2007; Raguž, 2007, pp. 57-70). Consequently, our reflections on ourselves, the world, and the meaning of our life have changed, altering the foundations of identity (Pera, 2009). We settle our ideas, goals, and needs within the limited borders of the world, making them material and profane, and losing sight of the horizon that transcends the visible world (Kovač, 2018, pp. 81-114; Gabriel, 2005, pp. 211-225).

Some theologians and philosophers argue that postmodernism is not anti-Christian, but post-Christian. More specifically, it has appropriated evangelical ideals and values, separated them from their bedrock (Jesus Christ) and turned them into cultural determinants (Dotolo, 2011, p. 152; Girard, 2004, pp. 211-225). According to renowned German philosopher Jürgen Habermas, our modernity is a direct product of the Jewish ethic of justice and the Christian ethic of love. Postmodernism, however, seems to have kept only the ethics of love, without the elements of the ethics of justice. This is what may be called the dictatorship of relativism, weak/superficial thought, etc. Consequently, in the context of our relationship with God and eschatological questions, it may be argued that the modern man is no longer afraid of losing eternal life, but is afraid of pain, suffering, helplessness, and dependence on others. Incidentally, in his book Enjoyment of Life (Lütz, 2015), Manfred Lütz delt with this enduring and increasingly ostensive transformation of secularization 
into secularism. In the book, Lütz asserts that instead of the soul and the spiritual, the postmodern man is increasingly concerned with the body, giving rise to an almost cult - the idolatry of the body, and in place of religion - the religion of health. The ultimate destiny is hardly even spared a thought. When it is considered, it is placed in the middle, not beyond earthly life. To this end, Lütz states that medicine controls the "quantity of eternal life", and psychotherapy is in charge of its quality (Lütz, 2015, p. 24). Observed from this angle, the spread of fear and anxiety seems to be a consequence of the idolatry of the body, whose fragility has been painfully exposed by the virus.

In the tide of socio-cultural change already mentioned above, evangelization has become increasingly challenging for the Church and requires participation of all baptized people, in keeping with their services, mandates, and charisms (Jurić, 2017, pp. 181-196). In its mission, the Church continues Christ's work of salvation. Simultaneously, it is like the Moon, which has no light of its own, but receives and reflects sunlight. The Church as the people of God in the Trinity discovers the source and exemplar of action. The love of God the Father, the service of His Son Jesus Christ, and the building up by the power of the Holy Spirit is the source and the blueprint for the fulfillment of the Church's mission (Asolan, 2011, pp. 13-16). As it is always done in specific circumstances, it is necessary to know them well.

Another prerequisite is a good grasp of the faith and eloquence in speaking about God and his relationship with people, especially in the most sensitive moments in life. After expounding on the context of the proclamation of the gospel in this chapter, the following section deals with the Christian concept of God and how we experience his presence in the world.

\section{Ways of talking about God during the coronavirus pandemic}

On the one hand, European cultural identity has indisputably grown under the strong influence of Christianity; on the other, what was initially a healthy emancipation from the yoke of religion (secularization) has over time turned into its progressive exclusion from social life and thrust into the private realm (secularism) (Ratzinger, 2005; Woods, 2009; Koch \& Smith, 2007; Murray, 2018; Murray, 2020). In postmodernity, religion has certainly not completely vanished (although many have anticipated and announced its dissipation) - it has simply changed. Due to the increasing stratification of society, it has become something of a "product" of personal choice (Borras, 2013, p. 178; Pace, 2020, p. 11). In other words, religious institutions no longer hold "dominance" over the sacred, and religious education of the individual in society has all but vanished (societas cristiana); the sacred has become a "matter" of free choice in the burgeoning market of religions and spirituality (Asolan, 2020, p. 106).

\section{Transcendence through kenosis}

How can we speak about God today? Where is God in the age of the coronavirus pandemic? Can his presence be felt in this time of universal crisis and suffering, especially by those directly affected by the coronavirus and their loved ones? This question presents one of 
the major and most complex challenges when discussing the relationship between God, evil, and suffering in the world. Various theologians and philosophers throughout history have tackled this topic. In his letters from his death cell, Dietrich Bonhoeffer, a German evangelical theologian and martyred anti-Nazi resister, paved the way for the theology of "non-religious Christianity," a horizon of faith that renounces the idea of an almighty God who dwells somewhere above us and accepts true transcendence in kenosis, in the man who - following in Jesus' footsteps - unconditionally sacrifices himself for others (Halík, 2020, p. 13). Kenosis (Greek: Kévoбıৎ) means enfeeblement, humbling. In the Christian context, it refers to the attitude adopted by Jesus Christ, the Son of God, in His incarnation for the salvation of man. For Bonhoeffer, transcendence is not some boundless and inaccessible chore; above all, it is our accessible neighbor in his or her need (Bonhoeffer, 1974, p. 165). Put as succinctly as possible, God may be tangibly experienced through the relationship with our fellow man, following the example of unconditional love of Jesus Christ. He is the model of coming to the Father and forging a personal relationship with him. We can glorify God and form a relationship with him by living how Jesus taught us in the Gospels.

H. U. von Balthasar, a Swiss Catholic theologian, also ruminated on the paradox of kenosis, the expression of Christ's deliberate self-giving. Dwelling on the Christological hymn in the Epistle to the Philippians (Phil 2:6-11), von Balthasar concluded that "this is a universally decisive turn of considering God, who is ultimately not an 'absolute power', but 'absolute love', and whose sovereignty is not manifested in the fact that what belongs to him, he keeps to himself, but that he freely renounces it [...] The self-annihilation of God (in incarnation) has its ontological possibility in God's eternal self-denial, his threefold gift" (Von Balthasar, 1971, p. 189). Pope John Paul II also spoke about the importance of understanding kenosis in his encyclical Fides et ratio. In this work, he stressed that it is precisely the correct understanding of God's kenosis that is the main task of theology. In Pope's words, it is "a grand and mysterious truth for the human mind, which finds it inconceivable that suffering and death can express a love which gives itself and seeks nothing in return" (Ivan Pavao II, 1999, p. 93). The Christian contemplation of God, therefore, starts from kenosis, a deliberate act of compassion and God's immeasurable love (in Christ) for all men. The Christian image of God, therefore, is painted in the tension between absolute power and absolute love. The absolute power, paradoxically, reveals itself in its readiness to completely renounce all power (Ratzinger, 1972, pp. 171-172). Love, then, and not power, is what makes God seem closer to people.

\section{The crucified God}

Another evangelical theologian, Jürgen Moltmann, known for his theology of hope and the theology of the cross which greatly influenced modern Protestant and Catholic theological thought in recent decades, speaks of a God who is not deistic but present - a compassionate God, sensitive to the affairs of the world and man (Moltmann, 2008; 2018). All human suffering is also God's suffering. The Christian God is not some immutable god of Greek philosophy, which could not conceive of a suffering God; this God suffered and was killed at the altar of human evil. Greek philosophers associated suffering with the changeable quality of creatures. In their view, only those who are changeable, imperfect - in short, human - can suffer; God, who is unchangeable, cannot. Unlike the gods of Aristotle and 
Plato, who are deprived of love, the Christian God is a crucified God - crucified for love. Pointing out the difference between these notions, Moltmann notes: "A God who cannot suffer is poorer than any man. For God who is incapable of suffering is a being who cannot be involved. Suffering and injustice do not affect him. [...] So, he is a loveless being. Aristotle's God cannot love; he can only be loved by all non-divine beings by virtue of his perfection and beauty, and in this way draw them to him. The 'unmoved Mover' is a 'loveless Beloved.”' (Moltmann, 2018, p. 258).

In Moltmann's theology of the cross, God and suffering are not at odds, for God's being is manifested in suffering, and suffering is manifested in God's being. God's being itself entails the ability to suffer because God is love (1 Jn 4:16), and love is best expressed in suffering, in the willingness to suffer for the benefit of another (Moltmann, 2018, p. 265, 269; Pehar, 2011, p. 429). Thus, God is not a 'cold celestial force', an unmoved mover or omnipotent energy deprived of a relationship with man; God suffers for his love; in Christ's kenosis, God self-manifests as a compassionate God. God suffers in His divine way. His capacity for suffering changes our perception of God and Jesus Christ, casting him as a companion and co-sufferer of men, rather than a distant, deistic god. Furthermore, if God were incapable of suffering, he most certainly could not love. The fact that Christians believe that their God is love and that He sacrificed himself out of love to liberate people from the curse of the Law (Gal 3:13) opens up a gateway toward understanding why God allows suffering in the world. Suffering is the price of love, a space for witnessing love. God, who has himself suffered, suffers alongside every innocent. He suffers with everyone who suffers for love (Moltmann, 2018, p. 299, 323).

\section{Compassionate God}

Even as the neighboring peoples came up with their own explanations for worldly evil in their mythologies, Israel has always been a "land of wailing", of seeking answers to the difficult questions of evil and suffering in the world (Halík, 2020, p. 14). Today, Christian theology has inherited the task. Johann Baptist Metz, the recently departed German Catholic theologian, was best known for his "new political theology". He saw the Church as a community of remembrance; remembrance of the central tenets of Christianity - what God has done for people (memoria passionis - the memory of suffering) and what, at the same time, has existentially determined Christians (or should do so). It must never neglect the question of man's suffering by reducing it willy-nilly to man's sinfulness; nor should it merely assuage this suffering through God's suffering; suffering should be taken quite seriously (Metz, 2009, pp. 33-34). The memory of Christ's suffering (memoria passionis) is not a mere reminiscence; for the Church, it is a binding memory that entails a duty to another and his or her suffering (Metz, 2009, p. 216). This memory inspires paying better attention to the suffering of our peers and saves people from collective callousness and apathy. Only by accepting the suffering of others and our individual responsibility for suffering can we escape the sin that torments men (Metz, 2009, p. 119).

Metz, therefore, proposes a theology that will not steer clear of suffering, but pay heed to it; a theology that will not focus on God's answers, but on man's dissenting questions addressed to God. Such a theology, attentive to the experience of human suffering, should 
first and foremost be a theology of memoria passionis - a theology of compassion (Metz, 2009, pp. 242-243). Jesus' cross of and his cry on the cross are not minor considerations; they bind and require Christ's faithful to show solidarity with and compassion to every victim of violence and injustice. Consequently, Christians must never lull themselves into the superficial triumphalism of Christ's victory but must remain ceaselessly sensitive to human suffering in all its forms; they must do as mystics, with open hearts and eyes, especially in the face of booming popularity of Far Eastern "shut-eyed" mystics, blind to the outrageous suffering of the innocent and the even more outrageous indifference of society (Metz, 2006, p. 401).

\section{The present God}

Jesus defined the relationship with the neediest strata of society as a measure of love and belonging to that selfsame society. This is most clearly expressed in His words: "Whatever you did for one of the least of these brothers and sisters of mine, you did for me!" (Mt 25:40). This criterion of belonging to Him is truly unique and inspiring for every man. It can rightly be said that whoever immerses themselves in God in the Christian sense - emerges amongst the poor. In other words, true spirituality is not limited to the relationship with God, but it also has social implications. The reverse is also true - whoever lends a hand to the poor and the needy might as well have helped God himself because God identifies with the poor. This is confirmed by Jesus in the Gospel of John: "Whoever has my commands and keeps them is the one who loves me. The one who loves me will be loved by my Father, and I too will love them and show myself to them" (John 14:21). Love is, therefore, not only a measure of belonging to God, but also a way of initiating communication with Him.

Frequently, the religious search for God ends with God remaining hidden, silent, unreachable, and man lonely and disappointed in the search. In other words, it is habitually thought that it is man who builds paths to God, not God to man; that is to say, religion is taken as man's search for God, not God's search for man. However, this is not the case in Christianity. Christianity, unlike other religions, is not a system built around man's search for God, but a story of God's search for man. Since men cannot penetrate that which transcends them, which is above them, God humbled (incarnated) Himself and became a man (Benedikt XVI, 2010a, p. 128). In Christ, He revealed Himself to humans, befriended then, sacrificed Himself for them. He has stayed by their side through the sacraments and elsewise. "No one has ever seen God, but the one and only Son, who is himself God and is in closest relationship with the Father, has made him known" (Jn 1:18).

If God has addressed man, called him to co-operate, it is only because He has already prepared man to meet Him - has made man permeable to incentives from above. So found and accepted, men witness God in all activities, staying alert to avoid getting lost in "wellness" spirituality and social activism that is deprived of a relationship with God, and, so distanced from the Source, easily tires and confounds goals with means. To the modern ear accustomed to equality, non-discrimination, and political correctness, it sounds arrogant when we claim that there is only one way (through Christ) to God. Of course, this really should strike us as arrogant if it really were us humans who were the creators of pathways to God. However, if it were God (not humans) who built that path, then accept- 
ing that path from God is modesty, not arrogance. On the other hand, it is arrogant - rather than modest - to insist that other paths are as good as God's path (Kreeft, 2021).

When it comes to mitigating the suffering of people affected by the COVID-19 pandemic, we must be aware of what Jesus Christ has done and is doing for us in different ways, through events and people. When people open themselves to His prompting, the awareness of God's presence and action breed gratitude, hope, and faith. Either through patient endurance or committed care for those at risk in the pandemic, these contribute to the overall healing of society. It is very important to be with the vulnerable during the pandemic, to give them the opportunity to talk about God and suffering from their own perspective. They have something to say, and their words and experience hold power and authority much greater than the theoretical knowledge of others. In addition to personal experience and the experience of others, scientific research also points to the role of faith in faster healing and stable mental health (Cornah, 2006).

The theological thought of Bonhoeffer, von Balthasar, Moltmann, and Metz, although only summarized and outlined above, may serve as the basis for a theology that may help people recognize God in day-to-day life and become His collaborators as they live through the COVID-19 pandemic. All things considered, we may conclude that the Christian God is not only an object, but also an agent of love - a tangible, radical love for the sake of which $\mathrm{He}$ sacrificed Himself for people, setting an example for them. God, therefore, does not help people because $\mathrm{He}$ is omnipotent, but because $\mathrm{He}$ is compassionate and merciful - love incarnate. In His relationship with people, his eye is not primarily drawn to the sin but to the suffering of others and finding ways to alleviate it (Metz, 2006, p. 400). "That is to say that God's being is compassionate relationality in the manner of agape, which changes the meaning of His immutability into pathos as a sign of His being-in-himself and for-us" (Dotolo, 2011, p. 227). Logically, such a conception of God has implications for the way of life of those who believe in Him. This way of looking at God entails the adoption of his pedagogy - focusing on the sufferers (people on the periphery of life) with whom he identifies (Mt 25:40). Christianity is neither asceticism as an end in itself nor an escape into a sheltered oasis of piety; rather, it is the acceptance of Christ's path, which involves co-suffering with the neediest (Cosentino, 2021, pp. 18-20).

\section{Tangible steps for the church to mitigate the impact of the SARS CoV-2 pandemic}

\section{Discovering the meaning of suffering (life)}

The coronavirus pandemic has prompted reflections on the fundamental questions of life. This is especially true of the meaning of life, the meaning of pain and suffering, and how we face them. For most people, these are some of the greatest problems in general. In contemplating these complex questions, one should first and foremost shun simplistic answers offered by those who would ascribe suffering caused by a physical evil to God's punishment. We must also reject voices that claim that God has nothing to do with human suffering as He does not exist (Vučković, 2020b, p. 8). We have to remember that suffering 
is inherent to (mortal) life. Pain and suffering have been logical consequences of human fragility from our inception (Peterson, 2018, pp. 353-355). They can be taken as punishment, tragedy, temptation, but also as a lesson and a completely natural fact of life. Pain and suffering can separate, alienate, and isolate a person, but they can also unite, deepen solidarity and empathy, and improve relationships. Heidegger believed that we cannot live authentically lest we accept our own mortality/contingency (Heidegger, 1988, p. 289, 326). Hans Jonas also recognized death as a precondition for birth, because every beginning implies a certain end. He feared the great ignorance of the fragility of the human being, recognizing it as a great threat to all mankind. More specifically, he feared a future scenario where the greatest power is coupled with the greatest emptiness, and the greatest capacity with the least knowledge of the ultimate meaning of life (Jonas, 1979/1984, p. 23).

Life can be beautiful when it is designed. On the other hand, man cannot create meaning, but can only receive it. As a young theologian, Joseph Ratzinger wrote: "Meaning, that is, the ground on which our existence as a totality can stand and live, cannot be made, but only received" (Ratzinger, 1972, p. 49). It can, of course, be received from the Creator of life. The Creator of life determines its meaning, much like we determine the meaning of everything/device we create. Pope Benedict XVI warned against the fundamental clash between Westerners and God. It lies in the fact that "the key to Christianity is the faith that God loves us and heals us through suffering” (Benedikt XVI, 2010a, p. 126). In contrast, modern humans have no problem accepting the fact that God loves us and that love is the driving force of all societies. However, we have a large bone to pick with the latter part of the statement - namely, that God heals man through suffering, firstly through His own suffering in the person of Jesus Christ, and then through personal suffering of men. Rejecting suffering as an inherent part of our lives is one of the fundamental features of our age. It is also the biggest bulwark of atheism.

If there is no point to suffering and life (because there is no God), then humans are the most wretched of all creatures. They have been endowed with the greatest longing that they cannot fulfill. However, if there is no God, and, consequently, no final justice, only nothingness, man will eventually shut down like a run-down computer - why would man then strive for the highest values in life? Why would they bind us if they were not given to us by the divine mind and if they were not engraved by the Creator into the human heart, into the deepest longings of men? In this sense, atheism, which implies nothingness after death, is the gravest insult to man's deepest longings and human moral sentiment (Lennox, 2020, p. 49). If might (evil, injustice, violence) ultimately makes right, what is the point of living? After all, might not the assumption of nothingness be seen as a permission to do any nefarious deed - as none of it will come due anyway? Is it not the case that atheism - not religion - is an insidious opium of humanity? This is exactly what Czesław Miłosz, a well-known Polish philosopher, writer, and Nobel laureate in Literature, once wrote about the old Marxist idea that religion is the "opium of the people" (Miłosz, 1998).

Believers design their lives by joining their pain and suffering to that of Christ and dedicating them to the salvation of the world or the conversion of sinners (Vučković, 2020a, pp. 393-394). In this way, through their suffering, they are united with Christ's suffering on the cross, by which He opened the door of salvation to the world. They also join so many saints, who, having endured the suffering of the world, entered into heavenly glory. 
Understood in this way, suffering does not isolate; on the contrary, it unites the sufferer with others, making his or her life easier. It has become especially important today to talk about the meaning of life and persevere in defending the dignity of life, from conception to natural death. In contrast, in recent decades, the talk of the West has been all about the quality of life. Quality of life seems to have thus become the meaning of life. However, quality is changeable and is habitually measured by the absence of suffering. Therefore, when suffering cannot be removed, life seems to lose its meaning and dignity; consequently, euthanasia is often imposed as a "humane solution."

\section{To reject suffering is to reject love}

Modern men seem to have forgotten that by rejecting suffering, we also reject love, because suffering is the price of love. In other words, love entails sacrifice and self-denial. Without them, there is no love. Suffering is a part of life and needs to be accepted as such. Without accepting suffering, death, or the limitations that mortal life implies, man moves away from himself (Heidegger, 1981, p. 201). By not accepting suffering, he distances himself from others and makes society an even colder and more unbearable place to live. By accepting suffering, man builds himself and society. This is visible now, during the COVID-19 crisis, e.g., the sacrifice made by doctors and nurses, or in the case of war the sacrifice made by veterans, firefighters in the event of a great fire, etc. Christ associated suffering with love. In our case, it is often the result of love; care for our loved ones. The suffering of one man gives birth to love in another. If empathy and compassion are absent, the life of people who suffer becomes unbearable (Jores, 1998; Ivančić, 2006, pp. 118-125). After all, it can also be a way to maturation, and ennoble the individual and society. In Crime and Punishment, Dostoevsky himself exclaimed that he could not imagine a great person who had not suffered: "Suffering and pain are always obligatory for a broad consciousness and a deep heart. Truly great men I think, must feel great sorrow in this world" (Dostojevski, 2004, p. 245). The transhumanist aspiration to remove human "flaws" (old age, vulnerability...) and create perfection is in fact contempt for men, an attempt to dehumanize men in the name of progress, often reducing humans to experimental subjects. But human life is not a subject but something "more than mere bios" (Benedikt XVI, 2008, p. 48). Precisely due to the fact that we have an identity, "there are no achievements, however noble, that could justify experiments on humans” (Benedikt XVI, 2008, p. 48).

Fragility is an integral element of human nature, an expression of humanity, a source of compassion and love. This is not to imply that people should not strive to improve their living conditions and health care. Progress should be made, but not to the detriment of men. Not every progress is a true progress. It has become an increasingly ambivalent phenomenon, as pointed out by many, regardless of their religious affiliation (Jonas, 1989; Galimberti, 1999; Vučković, 1999, pp. 17-30; Tomašević, 2015, pp. 171-177). In other words, progress goes hand in hand with the progression of destructive forces. Therefore, we must not overlook the danger that a spiritually immature man may fall "under the wheels" of our own development that has turned against us. Holistic development is a pressing concern for our society, and it is tirelessly advocated by Pope Benedict XVI in Caritas in veritate (Benedikt XVI, 2010b), as well as Pope Francis in Evangelii gaudium (Franjo, 2014) and Fratelli tutti (Franjo, 2020e). The tiny, almost invisible virus is an unexpected and 
rude reminder of the fragility of human health, as well as the reciprocity and mutual conditioning between our own happiness and the happiness of others. People are becoming increasingly aware of the fatigue caused by the 'tyranny' of fun, success, and popularity. It has become evident that men must slow down and preserve millennial values instead of feverishly changing them. Paying attention (often neglected) to the eschatological dimension of faith, i.e., the awareness that life on earth, although immensely valuable, is not the only life, also helps in this relativization of short-lived earthly gains. Death is not the end of everything; rather than just a loss, it is also a gain, as convincingly expounded on by St. Paul in his epistles.

Of course, believers have not solved the problem of suffering; however, they can minimize it through acceptance and personal engagement. In his book Where is God in a Coronavirus World?, Lennox explains that a Christian is not so much someone who has solved the problem of pain, suffering, and the coronavirus, but a person who has learned to love in the face of suffering. The Christian believes in a God who has Himself suffered but has also risen above evil and death and will return to judge all creation (Lennox, 2020, p. 51). A person who believes in Jesus will receive forgiveness of sins, be reconciled with God, and obtain new life. In this point, Christianity is not in the running with other religions and philosophies, simply because none of them offer forgiveness, reconciliation with God, and eternal life as Christianity does (Lennox, 2020, p. 51). Accepting and giving meaning to suffering does not necessarily deprive suffering of its weight; rather, it facilitates coping. Knowing why we suffer helps us endure suffering more easily. Of course, when it comes to helping people through this crisis, merely listing the 'reasons for suffering' is not enough; we also need to provide concrete help, physical closeness (as much as possible), and empathy to mitigate the consequences of suffering. Since pain and suffering also depend on the "framing of meaning (lessness)" by the unfortunate, relationships with the sufferers and how we treat them are of significant importance. From our daily interactions, we understand that even a single word or gesture from a family member, doctor, nurse, or friend, as well as the prayer of a single person/community, can turn the tormented to God, that "framework of meaning", and reduce his or her suffering.

In other words, God can be found precisely when it seems to us that He has forsaken us. Faith in Christ's redemptive work on the cross offers the believer a different perspective on life. In this perspective, we win when we serve others, when we give ourselves away dying like a kernel of wheat in order to be born again to a new life (Jn 12:24). It is indeed in the embrace of one's own mortality, in its cognizance and voluntary acceptance, that God's grace and love that give meaning and security to life are revealed to us (Fužinato, 2020, pp. 459-460). In the wisdom of the heart, men will realize that other people, time, life, etc., do not belong to us, but that they are a gift to be treated responsibly. According to Guardini, man then realizes that "every being is greater than itself. Every event is more than just mere unfolding. Everything relates to something above or beyond oneself. Only then does it gain fullness. If this disappears, things and arrangements begin to empty, lose their meaning, and cease to be convincing” (Guardini, 2002, pp. 97-8). We then begin to suspect that we are not masters but guardians of being (Heidegger, 1996, p. 167). 
The believer also suspects that, although God created a world where evil is possible, it by no means unfolds according to His will. The meaning that is unearthed by men, especially in troubled times, does not stem from fleeting joys and distractions provided by the entertainment industry of the modern society, but from the willing acceptance of responsibility for oneself, for others, and for all creation. The value of a thing is reciprocal to its complexity (Peterson, 2021, p. 20; pp. 127-130; p. 148). We can only appreciate what we have fought for, what we have invested our own time, knowledge, and love in. Following the voice of conscience, taking responsibility for ourselves, others, and all creation, is the path that will open the door to the meaning and beauty of our lives (Peterson, 2021, p. 150). In this particular case, we are confronted with a number of forms of suffering caused both directly and indirectly by this coronavirus pandemic. We have been fighting the virus for almost a year and a half, but there is still no end in sight and no agreement on how to overcome the virus (Risch, 2020). Yet, as the world becomes ever smaller, networked, and threatened, consensus on how to best help the affected must be reached. Regardless of personal opinions on the pandemic and measures taken to curb it - everyone is free to think whatever they will - we still have the obligation to provide appropriate aid to the affected.

\section{Where am I in the era of the SARS CoV-2 pandemic?}

The real question to ask in the face of the coronavirus pandemic, as well as any other accident, illness, or death of family members and friends, is not just the most frequent plea on everyone's lips: “Where is God in my suffering?”; rather, we need to ask: "Where am I in relation to God and the suffering I am in? Where am I in relation to the sufferings of others? Is there anything I can do? How can I spur myself and others into action?” These queries help us open the door to God in our fragile moments of doubt and grasp a better picture of our own options. In doing so, we can testify to God's presence through deeds even as God remains hidden from us. God's "hiding” is in all likelihood part of His design. Indeed, God deliberately withholds absolute proof of His existence so that we are free to choose - to believe or not to believe in Him (Kreeft, 2021). Quoting Immanuel Kant, Joseph Ratzinger reminds us that God cannot be known in the realm of pure reason; however, he also proposes God, freedom, and immortality as postulates of practical reason - postulates that are a prerequisite for any moral action (Ratzinger, 2008a, p. 33). Either way, one thing is certain: believers - whether they like it or not, whether they are aware of it or not - provide proof of how real God is to them in their daily lives.

One can be even more specific in devising ways to minimize the hardships caused by the coronavirus pandemic. As well-attested by both theology and life experience, in every man there are germs of good and evil, the potential to do good and evil. God bestowed His gifts/ talents on men in the form of a seed. It is men's duty to grow them or to discard/bury them. If men choose to grow them, the Kingdom of God will flourish and His presence will shine on us. This is confirmed by Jesus when he says: "If a man loves me, he will keep my words: and my Father will love him, and we will come unto him, and make our abode with him" (Jn 14:23). Living by the commandments, then, is the way of knowing God's presence - rather than just developing cognitive abilities. God encourages us to build His Kingdom as an existential rather than a spatial category. He encourages, but does not compel. He has given 
us freedom, so we can choose to work with God or against him. Here, too, we may glean at least part of the cause of human suffering: it is the price of our freedom. Still, one thing is certain: God does not stand by in troubled times if believers heed His prompting. In this sense, one may go even further by concretely and self-critically acknowledging that more could have been done on the spiritual field even while observing the measures that have been in place in Croatia. This refers to, among other things, the underused option of celebrating Holy Mass outdoors, as, for example, which the Poles have done (Pace, 2021, pp. 30-31). This also refers to the option of holding more Holy Masses on Sundays and weekdays and giving catechesis outdoors and on-line. More could also have been done in terms of spiritual support using media, such as radio and television shows, open call-lines, or setting up office hours for those in need of spiritual guidance. This also applies to holding group prayers for the sick, as has been done in Spain (Pace, 2021, pp. 30-31), visiting those who live alone and delivering essentials, medicine, etc. By making additional sacrifices, Christians could have helped the community to better cope with the consequences of the pandemic and advanced the dimensions of communion and solidarity that are constitutive of the Christian mission of the Church.

The trials of various saints in the history of the Church teach that one may find true and genuine happiness not only in the absence of pain and suffering, but also, paradoxically, in their presence - in accepting and ascribing meaning to suffering. Of course, this is not a masochistic desire for suffering as a prerequisite for fulfillment; this is about maturity that allows us to understand suffering as an essential part of life and then let God and others love us and love in return through suffering. Throughout history, mankind has been hit by countless epidemics of cholera and plague small and great. In those difficult and life-threatening moments, priests and believers did not shut themselves in and leave the infected to fend for themselves, but they helped the sufferers and their loved ones (both spiritually and physically), rallying the whole of society to resist the evil that befell it as fully as possible. Monastery chronicles and other sources reveal that in doing so, they quite literally looked death in the eye with the conviction that "life changes, but does not subtract"; that life, not death, would have the final say. As an example, Split was struck by the plague in 1731 and 1732. All neighborhoods were infected - all except Dobri. The plague returned several times in the years to come, but Dobri was spared every time. The people of Split attributed the miracle to the intercession of the Blessed Virgin Mary, and Our Lady of Health started to be revered in Split. The Franciscans from the monastery of Our Lady of Health helped the infected in many ways, and two of them voluntarily (during the plague of 1732) stayed with the infected to comfort and hearten sacrificing their own lives: Fr. Mijo Batinić in Split and Fr. Dujam Vuletić in a lazaretto outside of Split. They remained there until the end of the epidemic and did not become infected (Zlatović, 1888, p. 222; Baras, 2021).

\section{Liberating people from fear}

Various scientists who have studied men's propensity for destructiveness and evil have concluded that the roots of evil stem from fear (Kierkegaard, 1992; Renz, 2017). We cannot fight fear with appeals. Fear inhibits and prevents solidarity with others. Only by freeing ourselves from fear can we become what we are in our nature: people who love (Neuner 
\& Zulehner, 2015, p. 45). However, how may we rid ourselves of fear and realize our core identity - that we are beloved children of God? This we may achieve with the help of others and faith that does not dwell as much on the question of the essence of God but rather on questions of human existence, and seeks to find the answers to the questions of suffering and the meaning of life (Vučković, 2008, pp. 39-57). Only after experiencing acceptance/love can we accept/love others. It would not be amiss to claim that a man who knows no health, knows no disease. He or she may be sick, but he or she does not experience it in the same way as healthy people do when they fall sick. To appreciate health, one must first have experienced health, have felt what it is like to be healthy. Only then do we become aware of the deficiency and the beauty of health, and begin to long for health with all our heart. Not before.

The same goes for everyone who is accustomed to evil: they have frequently suffered evil themselves, endured it, and have been shaped, even distorted by evil. As they have never experienced love, kindness, and acceptance, they do now know what those sentiments mean and cannot appreciate them. Likewise, they cannot show them to others. "Only the person who can remember can hope. Who has never experienced good and goodness simply does not know them” (Ratzinger, 2007, p. 14). They only know and expect to be treated with violence, aggression, and harshness. To cope with their own fear of people, they show aggression. Therefore, we cannot help them understand their shortcomings simply by drawing their attention to them because they possess no awareness of the fact that they have them. Even if they did, it would be only on the rational level, which is inadequate as it is quick to contrive reasons and justifications for actions. Everyone needs to experience goodness on an emotional level. We need to be shown our good sides so that we may regard ourselves from a different perspective, observe our own mistakes, and change. Without realization, there is no change. This understanding, which is not only intellectual, but also deeply vital, is made possible by faith. A man touched by the presence of the Spirit of Jesus, who works through those who cooperate with Him, rises above the horizon of egotism and opens himself or herself to the true values of life (Benedikt XVI, 2012).

This is the manifestation of the duty shared by all Christians: to open the eyes of others with goodness and help them see their own shortcomings; to break the shackles of fear and alleviate the hardships left in the wake of the coronavirus pandemic through closeness and concrete actions. In the society that has been ravaged by rampant individualism, we must first and foremost create new and support existing forms of Church communities, movements, and associations to bolster communion and build identity. This specifically means "taking the risk of living with the virus" (Pontifical Academy for Life, 2020b, p. 2). Many, especially health care personnel who are at the forefront of the fight against the virus, have already accepted the risk of falling victim to the infection. There is a risk not only of getting infected, but also of infecting others, especially those at risk. Nevertheless, we cannot isolate ourselves or the most vulnerable populations by halting life; we must accept the risk and our own and others' vulnerability, and interact with others while taking necessary precautions. We cannot go into specific advice on how to do this here, because every situation is unique and subject to the voice of conscience, as well as to the measures put in place by the competent authority. At the global level, we have a duty - according to our own means - to advocate solidarity that acknowledges the equal dignity of all humans, 
especially those living in dire economic straits. At this time, this primarily entails ensuring the availability of vaccines, as well as improving the overall situation in countries suffering various injustices (Iglesia, 2021).

\section{Paying attention to the collocutor}

When Christians talk about God, they often feel like clowns. This was already noted (in 1968) by the then-bishop and later Pope Benedict XVI in his illustrious book Introduction to Christianity, where he cited Kierkegaard. In fact, Christians are forced to speak with ease about such an important "matter", but they would rather remain silent. We are small, but speak of the immeasurable. We feel that our minds are too small to comprehend the Mystery that shall always remain a secret, whatever we say of it. Therefore, we can truly and rightly speak about God only when we renounce the will to understand Him (Ratzinger, 1972, p. 137). When confronted with the mystery, the human mind cannot help but seem ridiculous and bumbling. For how can we effectively and seriously claim that God is everywhere when no one has ever caught a glimpse of Him? Nevertheless, the Christian must speak and proclaim, even at the cost of seeming like a clown to one's collocutors. We must certainly pay attention to our companions to avoid giving generic answers or trying to answer questions that have not been asked. By learning the backgrounds of one's collocutors, their problems, interests, and longings, one might manage to proclaim the Gospel appropriately, but always starting from life. We may effectively speak about God only when we are able to recognize how our collocutor worships 'god' while he or she is still in darkness (Hadjadj, 2018, p. 104). Knowing our collocutors well helps shape how we talk to them and makes our story relevant. Understanding is the bridge that connects us with God by successfully overcoming the dangerous seductiveness of moralism and triumphalism. If our collocutor feels neglected, we may deliver a meaningful and sublime speech about God and yet completely miss the point - fail to communicate and interact, and accomplish just the opposite - and let our arrogance hinder of our message.

In speaking of God, one should always keep in mind that there is God, and there is the notion of God. It is worth taking heed of the words of Ludwig Wittgenstein, who cautioned that people do not have a problem with God but with their notion of God: "If you want to justify yourself with God, it means you have the wrong notion of God. You are in the realm of superstition. If you are angry at fate, you are mistaken. You need to change your terms. Satisfaction with one's fate should be the first commandment of wisdom” (Wittgenstein, 1997, p. 96). In the discourse on God, one should beware of traps that habitually catch atheists and fundamentalists, for example. Both are equally "obsessed" with God and speak of Him with an unbearable ease that offends true believers. For the latter, God is the ultimate solution to all gaps in our knowledge, an answer to even unasked questions; to the former, every mention of God is a cause for concern that would all but peter out if only God were to vanish from public discourse (Hadjadj, 2018, pp. 39-40). In contrast, the true believer is reluctant to talk about God. And when they do, instead of hemming and hawing, they let their life and deeds "speak" about Him, heeding John's advice to "let us not love in word, neither in tongue; but in deed and in truth" (1 Jn 3:18). Unlike stammers and stutters, this is the language that almost everyone understands. To merely praise God without loving His creatures as He loves them and failing to treat them as He commanded us (Mt 25:40) is to 
fail to understand the Gospel and the mission of the Church. However, to understand this well, we must first realize that the greatest power of persuasion stems not from rhetoric, but from ethics. Dialogue draws its greatest strength from moral character and consistent and authentic life. Aristotle himself also realized this in his Rhetoric (Aristotel, 1989, pp. 212-217).

\section{The parish community is a space for everyone}

In order to contribute to mitigating the consequences of the coronavirus pandemic, the church, and especially the parish community, should not be places where ready-made answers are doled out to questions that no one has even asked. Nor should they be places selling superficial optimism and cheap comfort. They should the least of all be places where God is used to "cover" every serious question about suffering and the meaning of life like a bandage - a mystery to put a halt to any deeper conversation before it has even had a chance to begin. The church as a community of believers should approach all people and their questions, dilemmas, and doubts with respect. It is a community that travels through life together; a community where we learn from each other what we have been taught by the Teacher. The Church exists primarily to bring people to the living God, so they can build a personal relationship with Him and then foster all other relationships from there - with people, animals, plants, things (Ratzinger, 2008b, p. 97). The church needs to pay particular attention to people who have been hit by the pandemic in one way or another. They should be offered spiritual and material help, as well as given space to tell other people about their experience of suffering and God in that suffering.

In this sense, it is particularly important to draw from the rich treasury of church history and harmoniously integrate the immutable doctrine and changing methods of transmitting the faith. One thing, however, must never be forgotten - the power of authenticity. In his work, St. Paul did not rely solely on brilliant rhetoric and refined strategies, but invested and exposed himself as a whole to proclaim Christ the Savior. Today, the weary Church in the West needs above all fresh enthusiasm and people who are passionate about God to pass on their experience of faith to others and give credibility to God in today's world. "We need men whose intellects are enlightened by the light of God, and whose hearts God opens, so that their intellects can speak to the intellects of others, and so that their hearts are able to open up to the hearts of others. Only through men who have been touched by God, can God come near to men” (Ratzinger, 2016b).

Man is a being of relationships. When the first, foundational human relationship - the relationship with God - is disrupted, other relationships also go awry (Ratzinger, 2016a, p. 2). To set a person free by allowing them to skip the demanding path of their deification is to set that person up for deception, direct them on the path of barbarism. There are many examples where certain ideologies did away with God in the name of social occupation, such as the recent communist episode in our own country's history (Erceg, 2020). As a result, true social responsibility has been eroded, with some people still being none the wiser. Therefore, from our perspective, if we want to bring up our children, pupils, or students to be good people, we must make a decisive contribution to progress, a just society, peace, and prosperity. In this vision, the parish community is a place where all inquiring minds 
have a place; where there are no forbidden questions; where we discuss, grow in faith, and learn to respect others and their opinions.

Christian gestalt pedagogy provides good opportunities for a lasting development in faith. Beyond the inevitable cognitive dimension, it also puts the affective, physical, and spiritual dimensions at the center of learning and strives to develop them using creative learning methods (working with texts, pictures, modeling, Bibliodrama, emotions, movements, etc. (Jurić, 2020, pp. 823-839). Certainly, the integrated synodal pastoral care requires coordinated action by all pastoral actors: pastors, pastoral personnel, pastoral and economic councils, movements, associations, communities... of all baptized faithful. In order to rebuild our society, we must first recover the family and parish (Ivan Pavao II, 1990, p. 26). Everything starts from there - from an individual who is open to inspiration from above. This was long ago argued by Chesterton, who urged that we do not need a Church that would change with the world, but a Church that would change the world. Specifically, he asserted that a church that would not change the evangelical ideal to conform to reality, but would change reality to fit the evangelical ideal (Chesterton, 2015, p. 145). The Church seeks to correct society by calling attention to the anomalies of our time; to a widespread culture of indifference, exploitation, and rejection of people as things, it responds with a culture of solidarity and recognition of the dignity of every human being; it parries the culture of individualism with a culture of community; it reacts to a pandemic of fear by accepting its own fragility and taking concrete actions to help those at risk. The Church, therefore, helps the faithful and all people by being open, being close to those in need, as well as providing concrete help. Its doctrine provides a horizon of meaning to guide us into the future. In this sense, faith is not just a set of rules or a list of rituals, but a force that raises us above the waves of life and introversion and directs us toward our fellow man and the common good. Faith builds and teaches us to take responsibility and outlines our lives in all situations, especially in the moments of suffering, pain, and loss of loved ones. Faith broadens horizons by placing the future in the context of meeting the Lord. The future, consequently, is not nothingness or a threat that forces man to feverishly hold on to the present moment of pleasure, but a space for the fulfillment of the Lord's promises. The best is yet to come. Awareness that the road ahead does not end in inevitable doom but a new life with God has repercussions for our present life as well: it fills us with hope, peace, and engaged anticipation. In conclusion, faith in God does not turn us passive; on the contrary, it makes us even more responsible for our fellow man and all creation. Our relationship with people and all creation is the image of our relationship with the Creator.

Provenance: Submitted.

Peer review: Externally peer reviewed.

Received: 24 June 2021 / Accepted: 10 December 2021 / Published online: 24 December 2021.

Funding: This research received no specific grant from any funding agency in public, commercial or not-for-profit sectors.

Authorship declaration: IJ is the sole author of the study.

Competing interests: The author completed the ICMJE Unified Competing Interest form (available upon request from the corresponding author), and declares no conflicts of interest. 


\section{ORCID}

Ivica Jurić (ํ) https://orcid.org/0000-0001-6400-0577

\section{References}

Anders, G. (2004). Et si je suis désespéré que voulez-vous que j’y fasse? Paris, France: Allia.

Aristotel. (1989). Retorika. Zagreb, Croatia: Naprijed.

Asolan, A. (2011). Perché Dio entri nel mondo. Lineamenti per una ri-comprensione teorica-pratica del ministero pastorale. Città del Vaticano. Vatican: Lateran University Press.

Asolan, A. (2020). Quale pastorale della fede in Italia? Un'introduzione al tema. Credere oggi, 40 (5), $105-122$.

Baras, F. (2021, Januar 19). Kužne pošasti u starom Splitu. Portal hrvatskog kulturnog vijeća. Retrieved from https://www.hkv.hr/izdvojeno/vai-prilozi/ostalo/prilozi-graana/33480-f-baraskuzne-posasti-u-starom-splitu.

Begić, A. \& Brgles, M. M. (2021, January 27). Moralni izazovi i zahtjevi krizâ i patnje. Informativna katolička agencija. Retrieved from https://ika.hkm.hr/novosti/dr-begic-i-dr-brgles-moralniizazovi-i-zahtjevi-kriza-i-patnje/.

Benedikt XVI. (2008). Ivan Pavao II. - Moj ljubljeni prethodnik. Split, Croatia: Verbum.

Benedikt XVI. (2010a). Svjetlo svijeta. Split, Croatia: Verbum.

Benedikt XVI. (2010b). Caritas in veritate. Zagreb, Croatia: Kršćanska sadašnjost.

Benedikt XVI. (2012). Fides quaerens intellectum. Retrieved from https://www.vatican.va/content/ benedict-xvi/hr/audiences/2012/documents/hf_ben-xvi_aud_20121121.html.

Benotti, R. (2021). Covid-19: preti in prima linea. Storie straordinarie di chi ha dato la vita e di chi non si è arreso. Milano, Italia: Edizioni San Paolo.

Bogdan, A. (Ed.). (2020). Koronavirus i mentalno zdravlje. Psihološki aspekt, savjet i preporuke. Hrvatska psihološka komora. Zagreb, Croatia: Croatian Psychological Chamber.

Bonhoeffer, D. (1974). Otpor i predanje. Pisma iz zatvora. Zagreb, Croatia: Kršćanska sadašnjost.

Borras, A. (2013). La parrocchia, casa di tutti. Rivista di clero italiano, 94 (3), 176-194.

Bradshaw, S., Bailey, H., \& Howard, N. P. (2021). Industrialized Disinformation: 2020 Global Inventory of Organized Social Media Manipulation. Working Paper 2021.1. Oxford, UK: Project on Computational Propaganda. Retrieved from https://demtech.oii.ox.ac.uk/wp-content/uploads/ sites/127/2021/01/CyberTroop-Report20-FINALv.3.pdf.

Cecchin, F. (2021). Dopo Coronavirus, una grande opportunità. Retrieved from https://www. chiesadimilano.it/news/chiesa-diocesi/dopo-coronavirus-una-grande-opportunita-317746. html.

Chesterton, G. K. (2015). Pravovjerje. Split, Croatia: Verbum.

Congregation for the Doctrine of the Faith. (2020). Note on the morality of using some antiCovid-19 vaccines. Retrieved from https://www.vatican.va/roman_curia/congregations/cfaith/ documents/rc_con_cfaith_doc_20201221_nota-vaccini-anticovid_en.html.

Cornah, D. (2006). The impact of spirituality on mental health: a review of the literature. Retrieved from https://www.mentalhealth.org.uk/sites/default/files/impact-spirituality.pdf.

Cosentino, F. (2021). Essere Chiesa a partire da Dio e dalle vittime. Orientamenti pastorali, LXIX (6), 17-24.

Čondić, A. (2013). Ustani, zove te. Bogoslovno-pastoralna razmišljanja. Split, Croatia: Crkva u svijetu.

Doljanin, Š. (2021). Marsovci kontra kovida groznog. Zagreb, Croatia: Salesiana.

Dostojevski, F. M. (2004). Zločin i kazna. Zagreb, Croatia: Globus media.

Dotolo, C. (2011). Moguće kršćanstvo. Između postmoderniteta i religioznog traganja. Zagreb, Croatia: Kršćanska sadašnjost.

Drugi vatikanski koncil. (1986). Dokumenti. Zagreb, Croatia: Kršćanska sadašnjost. 
Državni zavod za statistiku [Croatian Bureau of Statistics]. (2021). Učinci pandemije bolesti COVID-19 na društveno-ekonomske pokazatelje. Retrieved from https://www.dzs.hr/Hrv/Covid-19/ stanovnistvo-brakovi.html.

Erceg, M. (2020). Can communism have a human face? The testimony of a prominent Croatian Catholic intellectual Smiljana Rendić from the mid-sixties in Yugoslavia. In M. Marušić (Ed.), Croatia: Past, Present and Future Perspectives (pp. 219-244). New York: Nova Publishers.

Franjo. (2014). Evangelli gaudium. Radost evanđelja. Zagreb, Croatia: Kršćanska sadašnjost.

Franjo. (2015). Laudato si’. Enciklika o brizi za zajednički dom. Zagreb, Croatia: Kršćanska sadašnjost.

Franjo. (2016). Amoris laetitiae. Radost ljubavi. Zagreb, Croatia: Kršćanska sadašnjost.

Franjo. (2020a). Izliječiti svijet 1. Retrieved from https://www.vatican.va/content/francesco/hr/ audiences/2020/documents/papa-francesco_20200805_udienza-generale.html.

Franjo. (2020b). Izliječiti svijet 2. Vjera i ljudsko dostojanstvo. Retrieved from https://www.vatican.va/ content/francesco/hr/audiences/2020/documents/papa-francesco_20200812_udienza-generale. html.

Franjo. (2020c). Izliječiti svijet 9. Pripraviti budućnost zajedno s Isusom koji spašava i ozdravlja. Retrieved from https://www.vatican.va/content/francesco/hr/audiences/2020/documents/papafrancesco_20200930_udienza-generale.html.

Franjo. (2020d). Što ste bojažljivi? Kako nemate vjere? Retrieved from https://www.vatican.va/ content/francesco/hr/homilies/2020/documents/papa-francesco_20200327_omelia-epidemia. html.

Franjo. (2020e). Fratelli tutti. Enciklika o bratstvu i socijalnom prijateljstvu. Zagreb, Croatia: Kršćanska sadašnjost.

Franjo. (2021, April 4). Cjepiva su ključno sredstvo u borbi protiv pandemije. Informativna katolička agencija. Retrieved from https://ika.hkm.hr/novosti/papa-cjepiva-su-kljucno-sredstvo-u-borbiprotiv-pandemije/.

Fužinato, S. (2020). Pathos prolaznosti i kairos vremena. Diacovensia, 28 (4), 457-461.

Gabriel, K. (2005). Zdravlje - najviše dobro. Pogled na postmoderno shvaćanje ljudskog zdravlja. In: N. Ančić \& N. Bižaca (Eds.), Kršćanstvo i zdravlje. Zbornik radova međunarodnog znanstvenog skupa. (pp. 211-225), Split, Croatia: Katolički bogoslovni fakultet.

Galimberti, U. (1999). Psiche e techne. L'uomo nell'età della tecnica. Milano, Italia: Feltrinelli.

Gallo Marin, B., Aghagoli, G., Lavine, K., Yang, L., Siff, E. J., Chiang, S. S., Salazar-Mather, T. P., Dumenco, L., Savaria, M. C., Aung, S. N., Flanigan, T., \& Michelow, I. C. (2021). Predictors of COVID-19 severity: A literature review. Reviews in medical virology, 31(1), 1-10. doi: https://doi. org/10.1002/rmv.2146.

Girard, R. (2004). Promatrah Sotonu kako poput munje pade. Zagreb, Croatia: AGM.

Gomes, R. (2021, 29 May). India: more than 400 priests and nuns have died of Covid-19. Vatican news. Retrieved from https://www.vaticannews.va/en/church/news/2021-05/india-church-priestsnuns-deaths-covid19.html.

Guardini, R. (2002). Konac novoga vijeka. Split, Croatia: Verbum.

Hadjadj, F. (2018). Kako danas govoriti o Bogu? Antipriručnik za evangelizaciju. Split, Croatia: Verbum.

Halík, T. (2020). In cammino verso la maturità. In: Castellucci, E. \& Halík, T. \& Lafont, G. Cambiamenti d'epoca. La Chiesa nell'abraccio dello Spirito. Bologna, Italia: EDB.

Heidegger, M. (1981). A cheminent vers la parole. Paris, France: Gallimard.

Heidegger, M. (1988). Bitak i vrijeme. Zagreb, Croatia: Naprijed.

Heidegger, M. (1996). Kraj filozofije i zadaća mišljenja: Rasprave i članci. Zagreb, Croatia: Naprijed.

Hrvatska biskupska konferencija (Episcopal Conference of Croatia). (2021, January 19). Vjernici pred izazovom pandemije i potresa. Poruka biskupa Hrvatske biskupske konferencije sa 61. plenarnog zasjedanja održanog 18. i 19. siječnja 2021. u Zagrebu. Informativna katolička agencija. Retrieved from https://ika.hkm.hr/novosti/vjernici-pred-izazovom-pandemije-ipotresa/.

Iglesia, V. F. (2021, 19 June). L’urgenza di un accesso universale al vaccino contro il covid-19. $L a$ civiltà cattolica, 4104 (2), 528-541. Retrieved from https://www.laciviltacattolica.it/articolo/ lurgenza-di-un-accesso-universale-al-vaccino-contro-il-covid-19/. 
Ivan Pavao II. (1990). Christifideles laici. Vjernici laici. O pozivu i poslanju laika u Crkvi i u svijetu. Zagreb, Croatia: Kršćanska sadašnjost.

Ivan Pavao II. (1999). Fides et ratio. Vjera i razum. Enciklika svim biskupima Katoličke crkve o odnosu vjere i razuma. Zagreb, Croatia: Kršćanska sadašnjost.

Ivančić, T. (2006). Teološko-pastoralne dimenzije i perspektive čovjekova zdravlja. In: Ančić, N. A. \& Bižaca, N., Kršćanstvo i zdravlje (pp. 113-128), Split, Croatia: Crkva u svijetu.

Jakšić, M. (2021). Nazire li se pandemija depresije? Vjesnik đakovačko-osječke nadbiskupije, Časopis za pastoralnu orijentaciju, 149 (39), 74-75.

Jonas, H. (1979/1984). The imperative of responsibility: In search of an ethics for the technological age. (Hans Jonas and David Herr, Trans.). Chicago, USA: Chicago University Press.

Jonas, H. (1989). Das Prinzip Verantwortung. Frankfurt, Germany: Suhrkamp.

Jores, A. (1998). Čovjek i njegova bolest. Zagreb, Croatia: Oko tri ujutro.

Jurasić, D. (2021, 10 March). Vjenčanja u vrijeme korone: Nikad nismo imali manje sklopljenih vjerskih brakova. Večernji list. Retrieved from https:/www.vecernji.hr/vijesti/vjencanja-uvrijeme-korone-nikad-u-hrvatskoj-nismo-imali-manje-sklopljenih-vjerskih-brakova-1475109.

Jurić, I. (2017). The Ecclesial Movements and New Communities as Instruments of Formation and Evangelization. In: Jadranka Garmaz - Alojzije Čondić (Ed.), Challenges to Religious Education in Contemporary Society (pp. 181-196). Split, Croatia: Catholic Faculty of Theology.

Jurić, I. (2020). Iskustveno učenje na primjeru snova u geštalt pedagogiji. Bogoslovska smotra, 90 (4), 823-839.

Katekizam Katoličke Crkve. (2016). Zagreb, Croatia: Glas Koncila.

Kierkegaard, S. (1992). Der Begriff Angst. Stuttgart, Germany: Reclam.

Koch, R. \& Smith, C. (2007). Samoubojstvo Zapada. Zagreb, Croatia: Naklada Ljevak.

Kovač, N. V. (2018). Zdravlje - najveće dobro današnjega čovjeka i teološko-pastoralna perspektiva. In: Polegubić A. (Ed.), Sakrament bolesničkog pomazanja. Zbornik radova (pp. 81-114). Frankfurt, Germany: Hrvatski dušobrižnički ured.

Kovač, N. V. (2020). Izazovi religioznosti sekularnog doba. Bogoslovska smotra, 90 (4), 757-775.

Kreeft, P. (2021). The benefits of belief. Retrieved from https://assets.ctfassets.net/qnesrjodfi80/ 692KwkdvrySGcYUmGAQqU8/89e996bbd9f010df1cc1f571e2118baa/kreeft-the_benefits_of_ belief-transcript_0.pdf.

Langer, S. \& Halík T. (2021). Wir haben kein Monopol auf Christus!. Christ in der Gegenwart, 72 (21), 6. Retrieved from https://www.herder.de/cig/cig-ausgaben/archiv/2021/21-2021/wir-haben-keinmonopol-auf-christus/.

Lanza, S. (2008). Convertire Giona, Pastorale come progetto. Roma, Italia: Edizioni OCD.

Lanza, S. (2010). La teologia pastorale secondo la “scuola lateranense”, I Laterani: questioni di teologia pastorale, 1 (1), 13-64.

Lennox, C. J. (2020). Gdje je Bog u doba koronavirusa? Split, Croatia: Verbum.

Lütz, M. (2015). Užitak života. Protiv terora dijete, manije zdravlja i kulta fitnessa. Split, Croatia: Verbum.

Maccioni, R. (2021, 19 April). Coronavirus. Il sociologo Garelli: «Al tempo del Covid cresce il bisogno di Dio». Avvenire. Retrieved from https://www.avvenire.it/chiesa/pagine/cos-cresce-il-bisognodi-dio.

Mathieu, E., Ritchie, H., Ortiz-Ospina, E., Roser, M., Hasell, J., Appel, C., Giattino, C., \& Rodés-Guirao, L. (2021). A global database of COVID-19 vaccinations. Nature Human Behaviour, (5), 947-953. doi: https://doi.org/10.1038/s41562-021-01122-8.

Matulić, T. (2020). Činjenice i izazovi pandemije SARS-CoV-2. Bogoslovska smotra, 90 (4), 743-755.

Mette, N. (1997). Il Gesù difficile. L'invito a una prassi di sequela nelle condizioni attuali. Concilium, 33, (1), 33-47.

Metz, J. B. (2006). Prijedlog univerzalnog programa kršćanstva u doba globalizacije. In: Gibellini, R. (Ed.), Teološke perspektive za XXI. Stoljeće (pp. 395-407). Zagreb, Croatia: Kršćanska sadašnjost.

Metz, J. B. (2009). Memoria passionis. Provokativni spomen u pluralističkom društvu. Zagreb, Croatia: Kršćanska sadašnjost. 
Misselhorn, C. (2018). Artificial Morality. Concepts, Issues and Challenges. Society, 55 (2), 161-169.

Miłosz, C. (1998, 19 November). Discreet Charm of Nihilism. The New York Review. Retrieved from https://www.nybooks.com/articles/1998/11/19/discreet-charm-of-nihilism/.

Moltmann, J. (2008). Teologija nade. Istraživanja o temeljenju i posljedicama kršćanske eshatologije. Rijeka, Croatia: Ex libris.

Moltmann, J. (2018). Raspeti Bog. Kristov križ kao temelj i kritika kršćanske teologije. Rijeka, Croatia: Ex libris.

Murray, D. (2018). Čudna smrt Europe - Imigracija, indentitet, islam. Zagreb, Croatia: Puls.

Murray, D. (2020). Ludilo gomile. Spol, rasa, identitet. Zagreb, Croatia: Puls.

Neuner, P. \& Zulehner, P. (2015). Dođi kraljevstvo tvoje. Praktična ekleziologija. Rijeka, Croatia: Ex libris.

Ognibene, F. (2021, 1 April). Vite donate. Ventitré preti morti di Covid in un mese. Avvenire. Retrieved from https://www.avvenire.it/chiesa/pagine/vite-donate-23-preti-morti-di-covid-in-un-mese.

Pace, E. (2020). Lo stato della fede cattolica in Italia. Credere oggi, 40 (5), 9-24.

Pace, E. (2021). Resilienza da credenti. Vaccini sociali, tecnlogia spirituale e cominità virtuali ai campi della pandemia. Orientamenti pastorali, LXIX (6), 25-32.

Pehar, M. (2011). Od nužnosti nemogućnosti do izbora ljubavi. Teodicejsko traganje kao pitanje Božjega bića, na primjeru Moltmannova nauka o Bogu. Bogoslovska smotra, 81 (2), 423-443.

Pera, M. (2009). Zašto se trebamo zvati kršćanima? Liberalizam - Europa - Etika. Split, Croatia: Verbum.

Peterson, J. B. (2018). 12 pravila za život, Protuotrov kaosu. Split, Croatia: Verbum.

Peterson, J. B. (2021). Izvan reda, Još 12 pravila za život. Split, Croatia: Verbum.

Pontifical Academy for Life. (2020a). L’Humana Communitas nell'era della Pandemia. Riflessioni inattuali sulla rinascita della vita. Neaktualna razmišljanja o ponovnom rođenju života. Retrieved from http://www.academyforlife.va/content/pav/it/the-academy/activity-academy/ humana-communitas-in-the-age-of-pandemic---july-22-2020.html.

Pontifical Academy for Life. (2020b). Pandemia e Fraternità Universale. Retrieved from http:// www.academyforlife.va/content/pav/it/the-academy/activity-academy/pandemia-e-fraternitauniversale.html.

Raguž, I. (2007). Vjernik i nevjernik pod »unakrsnim pritiskom«. Charles Taylor o sekularnom dobu. Diacovensia, 15 (2), 57-70.

Ratzinger, J. (1972). Uvod u kršćanstvo. Zagreb, Croatia: Kršćanska sadašnjost.

Ratzinger, J. (2005). Europa. Njezini sadašnji i budući temelji. Split, Croatia: Verbum.

Ratzinger, J. (2007). Božji sjaj u našem vremenu. Zagreb, Croatia: Kršćanska sadašnjost.

Ratzinger, J. (2008a). Kršćanstvo i kriza kultura. Split, Croatia: Verbum.

Ratzinger, J. (2008b). Nazvao sam vas prijateljima. Split, Croatia: Verbum.

Ratzinger, J. (2012). Riječ Božja. Pismo - tradicija - služba. Zagreb, Croatia: Kršćanska sadašnjost.

Ratzinger, J. (2014). O vjeri, nadi i ljubavi. Split, Croatia: Verbum.

Ratzinger, J. (2016a). Djetinjstvo Isusovo. Split, Croatia: Verbum.

Ratzinger, J. (2016b, 17 March). Prazno Božje prijestolje i agonija europske kulture - iz pera Josepha Ratzingera. Retrieved from https://www.bitno.net/academicus/filozofija-academicus/praznobozje-prijestolje-i-agonija-europske-kulture/.

Renz, M. (2017). Erlösung aus Prägung: Ein neues Verständnis von Heilung. Psychologie und Theologie im Gespräch. Paderborn, Germany: Junfermann Verlag.

Risch, H. A. (2020). Early Outpatient Treatment of Symptomatic. High-Risk COVID-19 Patients That Should Be Ramped Up Immediately as Key to the Pandemic Crisis. American journal of epidemiology, 189 (11):1218-1226, doi: https://doi.org/10.1093/aje/kwaa093.

Selak, M. (2019). Zlo i naopako. Suvremene manifestacije zla i pokušaji njihovih pravdanja. Zagreb, Croatia: Naklada Jesenski i Turk.

Taylor, C. (2007). A Secular Age. Cambridge, USA: Harvard University Press. 
Tokalić, R., Viđak, M., Mahmić, K. M., \& Marušić, A. (2021). Antifragility of healthcare systems in Croatia and Bosnia and Herzegovina: Learning from man-made and natural crises. Lancet Europe, 9, doi: https://doi.org/10.1016/j.lanepe.2021.100216.

Tomašević, L. (2015). Etike “trećeg lica” i moralne vrednote. Služba Božja, 55 (2), 155-178.

Tsao, S. F., Chen, H., Tisseverasinghe, T., Yang, Y., Li, L., \& Butt, A. Z. (2021, 28 January). What social media told us in the time of COVID-19: a scoping review. Lancet Digit Health, Published Online. doi: https://doi.org/10.1016/S2589-7500(20)30315-0.

Vatican news. (2021, 14 January). Campagna anti-Covid in Vaticano. Vaccinati il Papa e l'emerito. Vatican news. Retrieved from https://www.vaticannews.va/it/papa/news/2021-01/vaticanocampagna-anti-covid-vaccinati-papa-francesco-benedetto.html.

Von Balthasar, U. H. (1971). Mysterium paschale. In: Mysterium salutis (pp. 44-55) 6. Brescia, Italia: Queriniana.

Vranješ, N. (2013). Pastoral danas. Izabrane teme iz pastoralne teologije. Zagreb, Croatia: Glas Koncila.

Vučković, A. (1999). Pojam odgovornosti. In: Vuleta, B. \& Vučković, A. (eds.) Odgovornost za život. (pp. 17-30), Split, Croatia: Franjevački institut za kulturu mira.

Vučković, A. (2008). Što je religija i čemu religija? Wittgenstein i religija. Bogoslovska smotra, 78 (1), 39-57.

Vučković, A. (2016). Gledaj, tvoja majka! Duhovne vježbe, Mladifest Međugorje. Bosia and Hercegovina: Informativni centar Mir Međugorje.

Vučković, A. (2020a). Bol i smisao. Crkva u svijetu, 55 (3), 391-394.

Vučković A. (2020b). Preface, In: Lennox, J. C. Gdje je Bog u doba koronavirusa? Split, Croatia: Verbum.

Wittgenstein, L. (1997). Denkbewegungen. Tagebücher 1930-1932, 1936-1937. edited by Ilse Sommavilla, Innsbruck, Austria: Haymon-Verlag.

Woods, T. E. (2009). Kako je Katolička crkva izgradila zapadnu civilizaciju. Zagreb, Croatia: Teovizija.

Zlatović, S. (1888). Franovci države Presvetog Otkupitelja i hrvatski puk u Dalmaciji. Zagreb, Croatia: Knjigotiskara i litografija C. Albrechta. 